\title{
A Requiem for the Social Administration Association
}

\author{
HOWARD GLENNERSTER †
}

In July 1987 at the age of twenty precisely, the Social Administration Association came to an untimely and inappropriate end. It had been founded at the high point of optimism about the effectiveness of collective social provision and it died when the prognosis for collective social action in Britain reached its nadir. The majority of members present at the Annual General Meeting of the Association felt, presumably, that a change of title might help turn the tide of history. Social policy sounds less dreary, more political, than social administration. The Journal is, after all, called the Journal of Social Policy. What makes the change rather more than a pointless gesture, I believe, is that the change actually symbolises what has been a major failing of social administration as an area of study. It has not been concerned with the administration of social institutions. Administration was not the proper concern of university teachers, far too low level, untheoretical and boring. It is certainly not something likely to get you notice and acclaim amongst one's colleagues and superiors on whom promotion depends. We could have called it 'welfare management' and attained respectability and fashionability too. But no, that carried implications of efficiency and cost cutting. That would never do. We studied the policymaking process, the clashes of ideology inherent in opposing views about the role of the state, the crisis in the Welfare State, the newest and most obscure Marxist interpretations, the applications of economic, political and social theory. Others in the older tradition continued to investigate the poor and the deprived, to draw attention to the inadequacies and inequities of the market. Market failures and equity arguments continued to be used to justify collective public provision.

Yet nowhere, or almost nowhere, did scholars take time to analyse in depth or theorise about how welfare bureaucracies actually worked at the local level. David Donnison (1963) had done so. Few followed (David Billis, 1984). Yet in the end social services have lost public support not because we failed to make the equity case with sufficient conviction and

† Professor of Social Administration, Department of Social Science and Administration, London School of Economics. 
eloquence, or reveal depths of poverty with sufficient rigour in the pages of the Journal of Social Policy but above all because ordinary people's experiences of the services have often been demeaning and downright inefficient.

It is not enough to say that this is because the consumers are poor and this side of a socialist utopia you can't do better. I spent part of this summer walking up and down filthy blocks of flats in different parts of the country with rubbish shutes that don't work; lifts full of garbage; racist graffiti on walls of Bangladeshi homes. Many tenants live on estates where nothing works or ever seems likely to work. It is difficult, then, not to ask fundamental questions about the nature of the bureaucratic incentives which make this a way of life.

The economists have an answer. Public choice theory argues that social service consumers can exercise no power of 'exit' and that 'voice' (tenants'participation) (Hirschman, 1970) is incapable of producing a real incentive for efficiency. Public servants merely maximise their own self interest (Niskanen, 1971). These new right attacks on public bureaucracies have force partly because they strike home but, also, because there is no coherent alternative view about what makes public bureaucracies work or could make them work better. That is our fault. If we had worried less about critical theory and more about cleaning people's rubbish we would have served humanity better.

That is not to say that social administrators should run courses in waste disposal, but it does mean we should devote more thought to understanding the nature of public sector and non-profit organisations. How do we provide appropriate structures to respond to consumers' demands, and ration scarce resources in ways that reflect political and professional preferences too? How do we maintain the motivation for efficiency in the absence of profit or the test of competition? It is our failure to grapple successfully with these issues, I believe, that will condemn our subject area. The retreat from social administration is not a hopeful sign. Is it not social policy and administration we should be studying?

\section{REFERENCES}

D. Billis (1984). Welfare Bureaucracies. Heinemann, London.

D.V. Donnison et al. (1963), Social Policy and Administration, Allen and Unwin. London.

A.O. Hirschman (1970), Exit. Voice and Loyalty, Harvard University Press, Cambridge. Mass.

W.A. Niskanen (1971), Bureaucracy and Representative Government, Aldine-Atherton, Chicago. 